\title{
Mulheres e ciência: uma história necessária
}

Pioneiras da ciência no Brasil.

MELO, Hildete Pereira de; RODRIGUES, Lígia Maria C. S.

Rio de J a neiro: SPBC, 2006. 47 p.

Num momento em que aproximadamente $80 \%$ das bolsas de pesquisa no Brasil ainda são destinadas a homens - apesar da grande expansão do número de mulheres nos bancos universitários - a pergunta que continuamos a fazer é por que, alcançada a graduação, as mulheres não encontram estímulo para avançar no importante caminho da pesquisa científica.

Neste ano (2006), o Encontro Nacional "Pensando Gênero e Ciência", promovido pela Secretaria Especial de Polític as para as Mulheres, possibilitou a abordagem de várias questões no sentido de perceber os limites que se colocam à chegada das mulheres ao topo de carreiras c ientífic as nas ma is diversa sáreas, especia lmente naschamadas tec nológicas, onde o predomínio masculino se faz notar ma is efetivamente.

Um dos livros lançados no encontro apresenta instigantes (embora resumidas) biografias de algumas das principa is cientistas brasileiras, ou formadas no Brasil, nascidas em sua grande maioria na primeira meta de do século XX. Estamos falando de Pioneiras da ciência no Brasil, de Hild ete Pereira de Melo e Lígia Maria C. S. Rodrigues, editado em março pela Sociedade Brasileira para o Progresso da Ciência (SBPC).

Outros livros, como O laboratório de Pandora, ${ }^{1}$ da socióloga Fanny Tabak, discutem a relação mulheres-ciência, apontando a importância vital da tecnologia para os países subdesenvolvidos e, ao lado disso, a pouca a tuaçã o feminina nessa área. Tabakaponta para a real possibilidade de maior desenvolvimento científico e tecnológico do chamado Terceiro Mundo com a inclusão da capacidade intelec tual da s mulheres em a tivida des científic as. Além disso, 0 afasta mento dasáreas que decidem política e socialmente os destinos dos países as torna invisíveis na vida pública, como coadjuvantes dos atores de um plano maior, criado por homens e a eles destinado. E isso se dá em nível mundial.

O feminismo mudou a ciência?, ${ }^{2}$ da norteamericana Londa Schiebinger, é outra obra de referência para o tema, apontando as transformações dos conteúd os de conhec imento pelo feminismo, a lém do papel das mulheres na ciência e as questões de gênero que permeiam 0 meio científic 0 .

Hildete P. de Melo é doutora em Economia e professora da Universidade Federal Fluminense (UFF), com uma consistente carreira inicia da em meio a os movimentos feministas do Bra sil dos anos 1970. Ĺ́gia Maria C. S. Rodrigues dedica-se à Física, disciplina em que se doutorou, e segue na elaboração e prática de pesquisas para o Centro Brasileiro de Pesquisas Físic as (CBPF); tem ta mbém participação histórica em grupos feministas.

Juntas, as autoras lançam-se à tarefa de propor novos desafios às mulheres que passam pelas universidades, mas ainda se encontram limitadas pelo ranço social que as quer ainda atirar ao domínio privado, atuando como uma "lei da gravidade" contra a qual se nec essita lutar a cada dia. As mulheres que conseguem transcender as paredes da casa - seu lugar tra dic iona Imente construído - muita s vezes optam pelos chamados "trabalhos femininos", longe dos postos de chefia e direção. As responsa bilidades advindas das questões de gênero não são poucas e colocam-se como entraves ao desenvolvimento no campo profissional e científic 0 .

Das dezenove cientistas pioneiras escolhidas, seis não são nascidas no Brasil, mas a qui desenvolveram suas atividades. Cinco outras são filhas de mães/pais estrangeiras/os. Duas tiveram pais professores de Matemática; outras duas casaram-se com cientistas que as incentivaram e ajudaram a impulsionar as carreiras. 
Notamosa importância de um meio familiar propício ao avanço profissional das mulheres, quando os pais já haviam aberto caminhos que puderam levarà pesquisa, quando elas se uniram a companheiros cientistas ou quando tiveram educação provinda de outros países - com padrões diversos de pensamento e conduta adotados, entre os qua is o incentivo às carreiras das filhas. Somados, esses casos compõem a maioria das biografias encontradas.

Esse curto apanhado nos possibilita refletir sobre as distinções na forma ção dessa s mulheres e perceber que, para além das questões de gênero, a cultura também fazia parte dosfatores de exc lusão das mulheres brasileiras da pesquisa científica naquele momento. Hoje outros fatores se fazem ma is evidentes, como as questões sóc ioeconômicas, além da permanente divisão do trabalho por sexo, que ainda é bastante forte na nossa sociedade.

É interessante percebermos aonde a determinação e a continuidade nas pesquisas pode levar. O sucesso nascarreiras dascientistas escolhidas mostra que elas quebraram os "telhados de vidro" dentro das instituições para as qua is trabalham ou trabalharam, e mesmo em suas vidas, com várias delas vencendo as barreiras do preconceito e afirmando-se no pioneirismo e na competência profissional.

O livro de Hildete Melo e Lígia Rodrigues contribui de maneira incisiva para essa discussão.
Alguns erros de grafia encontra dos em Pioneiras da ciência no Brasil certamente podem ser desconsiderados diante da importância do traba lho como fonte de consulta e reflexão, para melhor entend emos os ca minhos perc orid os por essas mulheres pioneiras, modelos de atitude e coragem para as pesquisadoras que se formam e trabalham neste outro século, pleno de avanços tecnológicos e intelectuais, mas que mantém obstác culos estabelecidos pelo preconc eito, que a inda representam pedras a serem removidas a talhadeiras e mãos.

São profundasas mudança sestrutura is que se fa zem nec essá ria sà construção da igualdade, dentro e fora do campo c ientífic 0 . Então, mã os à obra.

\section{Notas}

${ }^{1}$ TABAK, 2002.

2 SC HIEBING ER, 2001

\section{Referências bibliográficas}

SCHIEBINGER, Londa. O feminismo mudou a ciência? Trad. Raul Fiker. Ba uru: EDUSC, 2001. TABAK, Fanny. O laboratório de Pandora. Rio de J a neiro: Garamond, 2002.

Ana Maria Veiga Universidade Federal de Santa Catarina 